\title{
Ozone Pollution and Urban Mobility Scenarios in the São Paulo Megacity
}

\author{
Júlio Barboza Chiquetto \\ Rita Yuri Ynoue \\ Sergio Alejandro Ibarra-Espinosa \\ Flávia Noronha Dutra Ribeiro \\ William Cabral-Miranda \\ Maria Elisa Siqueira Silva
}

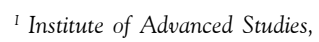
University of São Paulo, São Paulo, SP, Brazil.

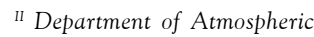
Sciences, University of São Paulo, São Paulo, SP, Brazil.

${ }^{I I I}$ Department of Atmospheric Sciences, University of São Paulo, São Paulo, SP, Brazil.

D IV School of Arts, Sciences and Humanities, University of São Paulo, São Paulo, SP, Brazil.

${ }^{v}$ Department of Geography, University of São Paulo, São Paulo, SP, Brazil.

${ }^{V I}$ Department of Geography, University of São Paulo, São Paulo, SP, Brazil.

\begin{abstract}
Air pollution is associated to poor urban mobility conditions, as in the megacity of São Paulo. Three scenarios of policies of driving restrictions were simulated using the WRF/Chem model, to assess the impacts on ozone pollution and the consequences for environmental justice: urban toll, sustainable transition, and vehicle free zone. Results show that the urban toll leads to a decrease of $20 \mu \mathrm{g} . \mathrm{m}-3$ in maximum 8 -hour ozone averages and the prevention of six hours of exceedances of the air quality standard. Sustainable transition was the most promising scenario, with a decrease of $50 \mu \mathrm{g} . \mathrm{m}-3$ and avoiding 22 hours of exceedances. The vehicle free zone did not show any advantages. For the implementation of adequate public transport systems, massive investments are required, in order to achieve better air quality with the greatest environmental justice possible, aiming towards the protection of human health along with a more democratic access to the urban spaces.
\end{abstract}

Keywords: Air pollution; environmental management; urban mobility; São Paulo; air quality modeling.

São Paulo. Vol. 23, 2020

Original Article

DOI: http://dx.doi.org/10.1590/1809-4422asoc20190008r2vu2020L6AO 


\section{Introduction}

Air pollution presents a complex environmental challenge in megacities, leading to many externalities, such as diseases, productivity loss and an overall decrease in quality of life (WORLD HEALTH ORGANIZATION, 2017). Worldwide, over 4 million deaths were attributable to outdoor air pollution in 2017 (HEALTH EFFECTS INSTITUTE, 2018). In Europe, $95 \%$ of the urban population is exposed to ozone $\left(\mathrm{O}_{3}\right)$ concentrations higher than the air quality recommendations from the World Health Organization (WHO) at least one day in the year. Ozone health effects may vary from irritation of eyes and upper respiratory tract, to increased skin ageing and headaches. Most importantly, high $\mathrm{O}_{3}$ concentrations are associated to an increased risk of respiratory problems (such as asthma and bronchitis), and for every $10 \mu \mathrm{g} \cdot \mathrm{m}^{-3}$ increase in ozone, the relative risk of overall mortality increases by $0.1 \%$ (AMANN et al., 2008).

Such health risks are evaluated by air quality standards (AQS). In the Metropoli$\tan$ Area of São Paulo (MASP), the ozone AQS of the São Paulo state (8-hour average $\geq 140 \mu \mathrm{g} \cdot \mathrm{m}^{-3}$ ) was exceeded on 32 days in 2016, in $90 \%$ of the monitoring stations (20 out of 22), and the attention level (8-hour average $\left.\geq 200 \mu \mathrm{g} \cdot \mathrm{m}^{-3}\right)$, on one day. This demonstrates that the 23 million inhabitants of the MASP are constantly under serious health risks from air pollution.

The transport sector is an important source of air pollution and greenhouse gases worldwide, particularly in megacities such as the MASP. According to the Environmental Agency of the State of São Paulo (CETESB), light and heavy-duty vehicles emitted around $96 \%$ of carbon monoxide (CO), 75\% of hydrocarbons (HCs), 66\% of nitrogen oxides $(\mathrm{NOx})$ and $40 \%$ of the inhalable particulate material $\left(\mathrm{PM}_{10}\right)$ in 2017 (CETESB, 2018). Vehicular pollution also leads to the formation of tropospheric ozone $\left(\mathrm{O}_{3}\right)$, a secondary pollutant, via photodissociation of $\mathrm{NO}_{2}$ by sunlight. However, volatile organic compounds (VOCs), such as the HCs, are also important for ozone formation, because they oxidize $\mathrm{NO}$ to $\mathrm{NO}_{2}$ in a series of reactions (BRASSEUR et al, 1999). This increases $\mathrm{NO}_{2}$ concentration, which undergoes photodissociation and leads to a net increase of $\mathrm{O}_{3}$. Studies have shown that the addition of $25-27 \%$ ethanol to gasoline, as well as the intensive use of ethanol as a fuel per se, widespread in Brazil, increase VOCs emissions from the aldehydes class, which are the most reactive VOCs for ozone formation. Furthermore, decrease in ethanol use was associated to a decrease in ozone concentrations (SALVO; GEIGER, 2014; ALVIM et al., 2017). However, ozone can also be consumed by $\mathrm{NO}$ or VOCs. Thus, the management of this pollutant is a complex interdisciplinary task, due to its intricate atmospheric chemistry characteristics, and from the point of view of several sectors of urban planning such as transport, land use and health (WORLD HEALTH ORGANIZATION, 2009; KRAAS; MERTINS, 2014).

Urban mobility intermediates how the population access goods, services, and their relationship to the urban environment as a whole (LUCAS, 2012; YAMAWAKI; SALVI, 2013). Heavy traffic congestion leads to many complications from delays in transporting goods to higher pollutant emissions and air pollution exposure. In a global study on urban mobility data, São Paulo was ranked as the 4th worst megacity in traffic conditions in the 
world, with 86 peak hours spent in congestion per year, and an average congestion rate of 22\% (COOKSON; PISHUE, 2017). The heavy traffic jams are a consequence of many factors, including the underdeveloped metro system in São Paulo $(101 \mathrm{~km})$ compared to other megacities of the same importance (Beijing - $690 \mathrm{~km}$, New York - $373 \mathrm{~km}$ and Mexico City - $200 \mathrm{~km}$; more information can be found in the Supplementary Material 1).

In Brazil, buses transport $70 \%$ of the urban population, but occupy only $25 \%$ of urban roads (LACERDA, 2006). According to the latest origin-destination survey, private vehicles transport about the same proportion of people as buses in the MASP, but the private vehicle fleet is a hundred times larger. Besides that, studies have demonstrated that personal exposure to traffic pollution is worse for bus commuters, due to longer trips, the time waiting at the bus stop near the traffic lanes, among other factors (CARVALHO et al., 2018), which shows that socioeconomic and environmental vulnerabilities produce synergic effects. Recent research was performed for São Paulo, indicating that the population from the MASP districts with the lowest HDI face longer travel times, which contributes to higher air pollution exposure and to their social exclusion (SLOVIC et al., 2019). The discrepancies between access to the city, use of the urban space, transport efficiency, per capita emissions and air pollution exposure, driven solely by socioeconomic status, is a strong sign of environmental injustice (ROBERTS et al., 2009).

Proper management of urban mobility presents opportunities to promote better social and environmental justice in megacities. For example, Bus Rapid Transit systems can decrease travel time and costs, while improving connectivity, as long as they are integrated with other transport modes and the housing sector (VENTER et al., 2017). Driving Restriction Policies (DRP) usually inhibit private vehicle use, and so, tend to decrease overall congestion in their target areas and encourage public transport use. In an extensive evaluation of the Congestion Charging Scheme in London, Kelly et al. (2011) found a decrease of 20 to $50 \%$ in the number of vehicles in the targeted area. Such studies show that urban mobility policies which encourage and prioritize public transport, including DRP, can result in more democratic access to the urban spaces.

Concerning air pollution, results point that DRP were fairly successful in decreasing pollutant concentrations, particularly primary vehicular pollutants, while for secondary pollutants, such as ozone, mixed results were obtained. The Congestion Charging Scheme in London led to a decrease of $9 \%$ in $\mathrm{NO}$ annual averages inside the restriction zone, and up to $23 \%$ outside of the zone. CO concentrations decreased by up to $25 \%$ inside the area; meanwhile, for $\mathrm{NO} 2$ and PM10, no clear trend was found, probably derived from its significant variety of sources, as well as their secondary fraction (KELLY et al., 2011). Wang et al. (2009) showed a decrease of $19 \%$ of CO, as well as a $22 \%$ improve in traffic conditions due to aggressive mitigation policies, which included DRPs, during the China Olympic Games in 2008. However, ozone increased by 25\% in downtown Beijing, possibly due to a change in the NOx/VOCs ratio which favoured ozone increase. This demonstrates the complexity of the impacts of DRP over secondary pollutants, such as ozone. In Mexico City, after a DRP which took place only on Saturdays was implemented, there was no evidence of decrease in pollution nor in private vehicle use, which might 
be attributed to the low quality of public transportation (DAVIS, 2017). Therefore, DRP must be implemented along with public transport improvements, or they might result in less access to the city and longer commuting times. Holman et al. (2015) concluded that several factors affected the impacts of DRP over air pollution such as which pollutants and type of vehicles were considered, the size of the restriction area and the meteorological conditions at the time of the study. Such complex issues should be carefully considered before implementing these policies and interdisciplinary studies should be performed for each location, or at least, serve as a reference for comparable conditions.

Given the high ozone concentrations in the MASP and the many uncertainties concerning the impact of DRP over pollutant concentrations, particularly for secondary pollutants, the objective of this study was to evaluate three hypothetical DRP/urban mobility scenarios in the MASP as to their efficiency to decrease ozone concentrations, and also discuss the environmental justice aspects of each scenario. A period of meteorological conditions favourable for high ozone concentrations was chosen for analysis and simulations were performed with the WRF/Chem model (GRELL et al., 2005). Due to their potential for co-benefits to improve air quality and traffic problems, we consider the results relevant for environmental and urban policy evaluation aimed at improving air quality, urban mobility, and a more democratic access to the urban spaces, particularly for complex megacities in the developing world.

\section{Data and Methods}

We chose the period 28/01/2014 00Z to 02/02/2014 00Z for simulation, characterized in the study area by high insolation, pressure and air temperature, which favoured pollutants concentration (particularly $\mathrm{O}_{3}$ ). This period presented intense regional temperature contrasts between the ocean and the continent, which strengthened the local circulation system of sea-land breeze (CARRERA; SILVA DIAS, 1990).

The atmospheric model WRF/Chem version 3.2.1 was used with the emission scheme of Andrade et al. (2015). This version of the model was chosen due to the specific VOCs treatment available in this version, which considers ethanol as an explicit species (relevant for this study area because of the massive use of ethanol-fuelled vehicles in Brazil and the importance of VOCs for ozone formation). Vehicular emission estimates were based on emission factors published by CETESB (2010) and on tunnel observations, which assign emissions based on vehicle and fuel type. Then, emissions are adjusted by vehicle use $(\mathrm{km} /$ day $)$ and its temporal activity profile. Then, to better distribute emissions in space, they were multiplied by total road length in each $1-\mathrm{km} 2$ grid cell, in a way that areas with longer road lengths, emissions will be higher (refer to Andrade et al., 2015, for more details).

In order to avoid that road length alone determined emissions and caused errors (for example, a grid cell with high road length but located in a residential suburban area would have high emissions), a simple spatial adjustment was performed. Emissions of all pollutants were decreased in 20\% outside the urban centre of São Paulo, and in $80 \%$ on non-highway roads outside the urbanized area of the MASP (emission in highways were 
not reduced). This simple adjustment kept emissions in downtown areas higher than in the suburbs, as usually observed. The model validation is described in Chiquetto et al. (2018).

A control simulation was performed representing the "business as usual" scenario in the MASP (scenario A in figure 1). Sensitivity scenarios (B, C, and D, in Figure 1) were designed, in which changes in vehicular emissions were applied to simulate different DRPs in the study area. The expanded centre of São Paulo (Figure 1 b, c) is comprised of many districts around the old historical centre which concentrates much of its activities and where there is greater availability of public transportation, with many bus lanes and corridors and a metro system. There is a driving restriction currently in place in this area, in which vehicles are forbidden to enter on certain days of the week according to their license plate numbers (rodizio). So, we considered this area as a potential target for future DRP.

Three different scenarios were compared to the control case: urban toll (B), sustainable transition $(\mathrm{C})$ and vehicle free zone (D). These range from feasible scenarios in short-term future (D) to fairly possible scenarios in medium-term (B) to a far and utopic future $(\mathrm{C})$, and, all with different implications considering urban mobility, access to the city and potential air pollution exposure. To assess both the air quality and environmental justice aspects, we used the following steps:

1) Considerations were made about the implications of each scenario in the access to the city, urban mobility and potential for environmental justice;

2) Emissions were changed in each scenario according its urban mobility characteristics;

3) Air quality simulations were performed to provide answers as to their environmental impacts (results);

4) The combination of the access to the city, urban mobility and air quality impacts from the simulations will confirm the supposed environmental justice benefits for each scenario (qualitatively), following the recommendations from Martínez et al. (2018) in which the advantages and disadvantages should be taken into consideration when considering transport impacts, with a combination of qualitative and quantitative approaches (conclusions). A flowchart of this method can be found in the supplementary materials.

\section{Scenarios Description}

While scenario A represents business-as-usual conditions, scenario B represents a DRP of urban toll, in which a tax would be paid to enter the expanded centre. According to the literature (KELLY et al., 2011; HOLMAN et al., 2015), urban tolls decrease the number of vehicles which enter toll areas in Europe in about 20 to $50 \%$. So, to simulate the decrease in driving activity from an urban toll in the restriction area, overall emissions were decreased in 50\% in the expanded centre of São Paulo. To prevent that the emission decrease in the expanded centre led to an increase in emissions in the rest of the domain, the number of vehicles was decreased from 8 to 7 million, to reduce the total domain emissions in this scenario (if the total emissions were kept the same, the 
model would automatically increase emissions outside the expanded centre). We chose this procedure because, in this scenario, the resources acquired from the toll tax payment could be allocated to public transport investments inside and outside the expanded centre, increasing the availability and efficiency of public transport and thus decreasing the use of private vehicles for transportation. This led to a slight decrease in emissions outside the expanded centre in scenario B, compared to the control simulation (-7\%). Because this scenario simulates improvements in public transport, it would lead to shorter commuting times, which would also decrease population exposure to air pollution. The investments in public transport from the toll tax could lead to improvements in urban mobility, and together with the local decrease in emissions, promote potentially better environmental justice in the MASP. This scenario is reasonably feasible; it is not feasible to be implemented right away but is a possibility for a medium-term future.

Scenario $\mathrm{C}$ represents a utopic future situation, after a sustainable transition takes place in the transport system of the MASP. This scenario might be attained in the future if urban planning is prioritized, aligning urban mobility with land use through strategic directive plans focused on a more equal, human and environmental-friendly city. A public transport system with zero pollutant emission would operate in the expanded centre, entirely restricting the circulation of polluting vehicles in this area, focusing on systems such as a wide underground network, electric buses and cars, and non-motorized modes of transport. Besides that, this scenario assumes a plentiful availability and efficient integration between all transport modes outside the expanded centre in São Paulo, promoting intercity integration in the MASP. Outside the expanded centre, a driving restriction would take place in specific hours of the day, focused on limiting pollutant emission during the hours of higher sunlight and subsequent hours - when exceedances of the ozone AQS commonly occur, from 12 to 19 hours. This resulted in a substantial decrease in emission at these hours of the day in the whole model domain $(-52 \%)$. Because of the increased transport efficiency characterized by this scenario, urban mobility would be greatly improved, providing a more equal access to the city to the entire population via a well-developed public transport system. Such improvements would lead to low pollutant emissions as well as shorter commutes (which mean less air pollution exposure), so, this scenario potentially represents a much greater environmental justice in the MASP. This scenario was designed to confront more directly high ozone episodes, strongly linked to emissions under the availability of sunlight. Because it represents a very aggressive emission control, it was firstly based on the restrictions implemented during the Olympic Games in Beijing, such as the simulation performed by Wang et al. (2009). However, it would only be achievable in a long-term future, as a consequence of a series of policies.

In scenario D, emissions were completely removed from an area close to the centre of the domain (roughly equivalent to the São Paulo centre). However, it does not conform to administrative limits of the districts and is smaller than the expanded centre. In this scenario, no other changes were considered in public transport outside the restriction area, so the total number of vehicles remained at 8 million, which resulted in an increase in emissions in the domain $(+12 \%)$. This scenario could represent a near future situation where, with no other policies oriented towards improving public transport, private 
vehicle use would increase in the MASP, albeit not allowed inside the restriction area. This scenario was designated as Vehicle Free Zone. The local decrease in emissions could represent some environmental gains; however, the restriction of vehicles in downtown areas, without a better development of the transport system, could potentially represent a more difficult access to such areas by the population, so it is not optimized in terms of urban mobility and uncertain in terms of environmental justice. On the other hand, it represents the most readily feasible option concerning the policies evaluated for the MASP in this work.

Figure 1 (a, b, c, d) shows the model domain and characteristics of each scenario. 
Figure 1 (a, b, c, d) - MASP (thick black line), WRF/Chem model domain (blue square) and emission characteristics of the different scenarios: A-control (top left), B-urban toll (top right), C-sustainable transition (bottom left) and D-Vehicle Free Zone (bottom right). Emission is higher in grid cells represented by warmer/darker colours.
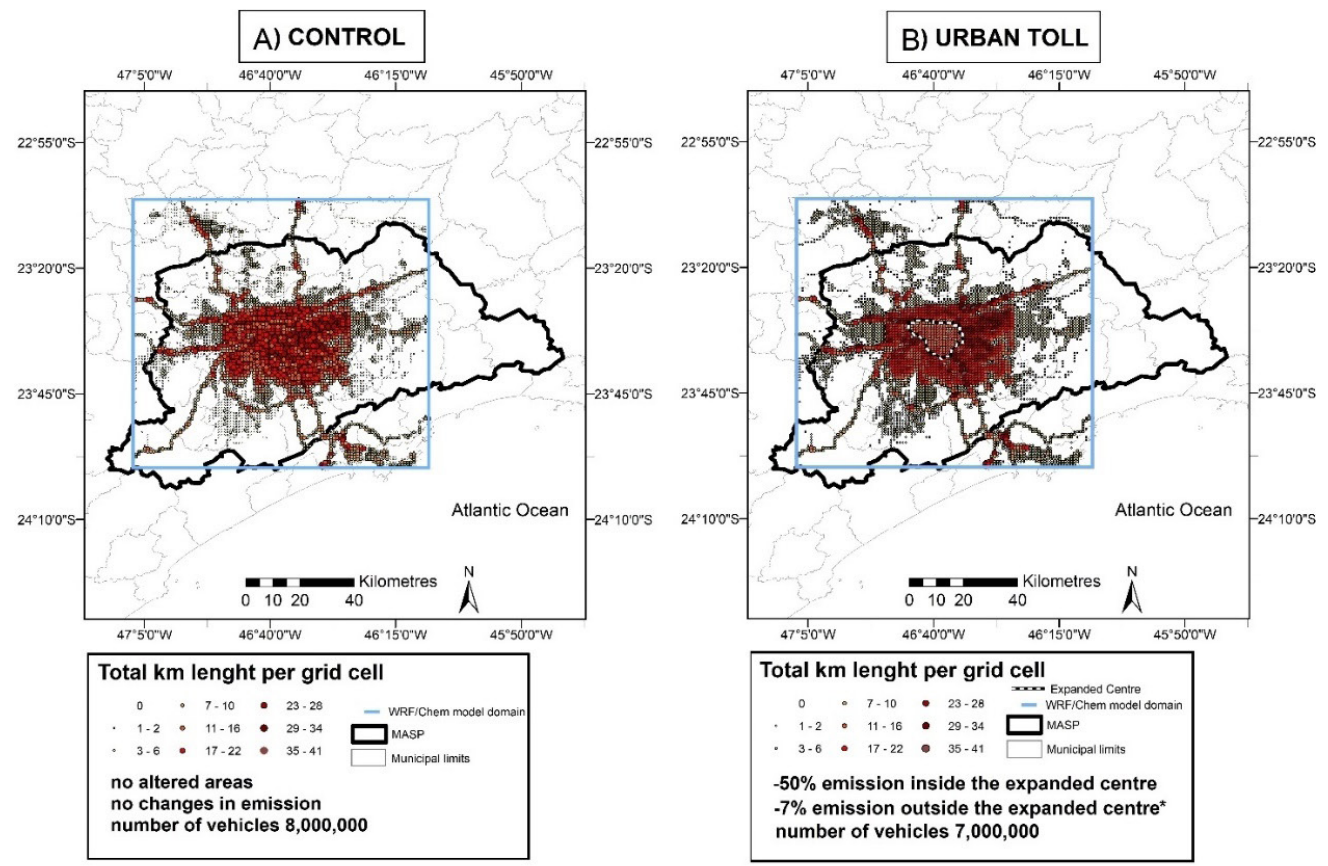

$-50 \%$ emission inside the expanded centre $-7 \%$ emission outside the expanded centre number of vehicles $7,000,000$
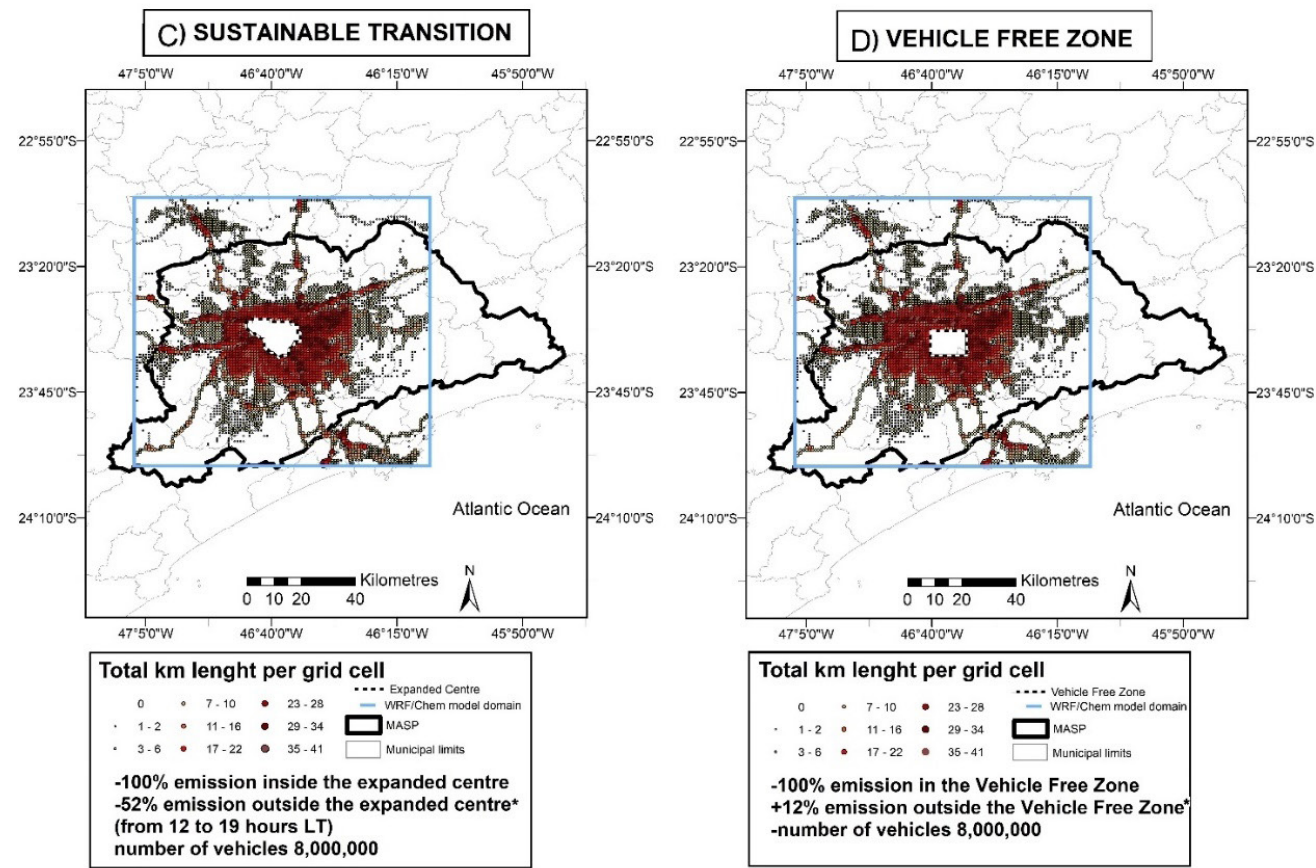

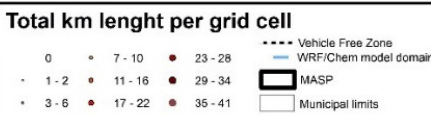

$-100 \%$ emission in the Vehicle Free Zone

$+12 \%$ emission outside the Vehicle Free Zone

-number of vehicles $8,000,000$

*taken from a sample location in the domain, in east Săo Paulo, and reflect average emission changes 
Source: prepared by the authors.

Results were evaluated by the differences in maximum ozone concentrations and in the exceedances of the ozone Air Quality Standard (AQS) which is currently an 8-hour average of $140 \mu \mathrm{g} \cdot \mathrm{m}^{-3}$ in the state of São Paulo. To check if the AQS is exceeded at a specific hour, the previous seven hours are added, and the average is calculated; this was performed for all hours in all scenarios, according to Equation 1:

$$
\text { AQSE }=\frac{T_{H}+T_{H-1}+T_{H-2}+\cdots+T_{H-7}}{8} \geq 140 \mu \mathrm{g} \cdot \mathrm{m}^{-3}
$$

Where AQSE = Air Quality Standard Exceedance

$\mathrm{TH}=$ concentration at the analysed hour

$\mathrm{TH}-\mathrm{n}=$ concentration $\mathrm{n}$ hours earlier than the analysed hour

A comparison of the total number of hours of exceedance of the AQS for the whole simulation period, among all scenarios, will be presented in table 2 . A few selected cases (specific 8-hour averages) were considered interesting from a scientific point of view to demonstrate the differences of the impacts of each DRP scenario on ozone concentrations, both spatially (area of exceedance) and in terms of concentrations levels (maximum concentrations). This should help to elucidate the main question of the study. Simulated wind speed and direction are also shown in each map, because this variable was important in determining the occurrence of high ozone episodes in each scenario.

\section{Simulation Results and Discussion}

Three situations were chosen to represent the differences among the modelled DRP scenarios. Higher concentrations were simulated mainly in the west portion of the MASP. This was caused by the intrusion of the sea breeze front in the beginning of the afternoon, with winds coming from the southeast. The interaction between wind direction and pollutant emission leads to their transport from southeast to northwest areas of the MASP, which was shown in another study for the MASP (CHIQUETTO et al., 2018).

The first hourly case chosen for analysis showed excessively high ozone concentrations over a wide area (Figure 2). On this day, several exceedances of the ozone AQS were observed in many monitoring stations in the MASP (CETESB, 2015). Our simulations indicated exceedance of the attention levels (8-hour average $>200 \mu \mathrm{g} \cdot \mathrm{m}^{-3}$ ). Maximum observed concentrations were very close to attention levels $\left(190 \mu \mathrm{g} . \mathrm{m}^{-3}\right)$ and they might have been exceeded in non-monitored areas of the MASP (CESTESB, 2105). 
Figure 2: Simulations in each scenario (A, B, C, D) at 18 LT, 29/01/2014: municipal limits (thin black contours), areas of emission change (thick black contours), wind direction and intensity (blue arrows, size '10' below each image $=10$ $\mathrm{m} . \mathrm{s}^{-1}$ ) and areas of exceedance of the AQS in the MASP (warm colour bar on the right, $\mu$ g. $\left.\mathrm{m}^{-3}\right)$. Green hollow contours indicate concentrations within the AQS.
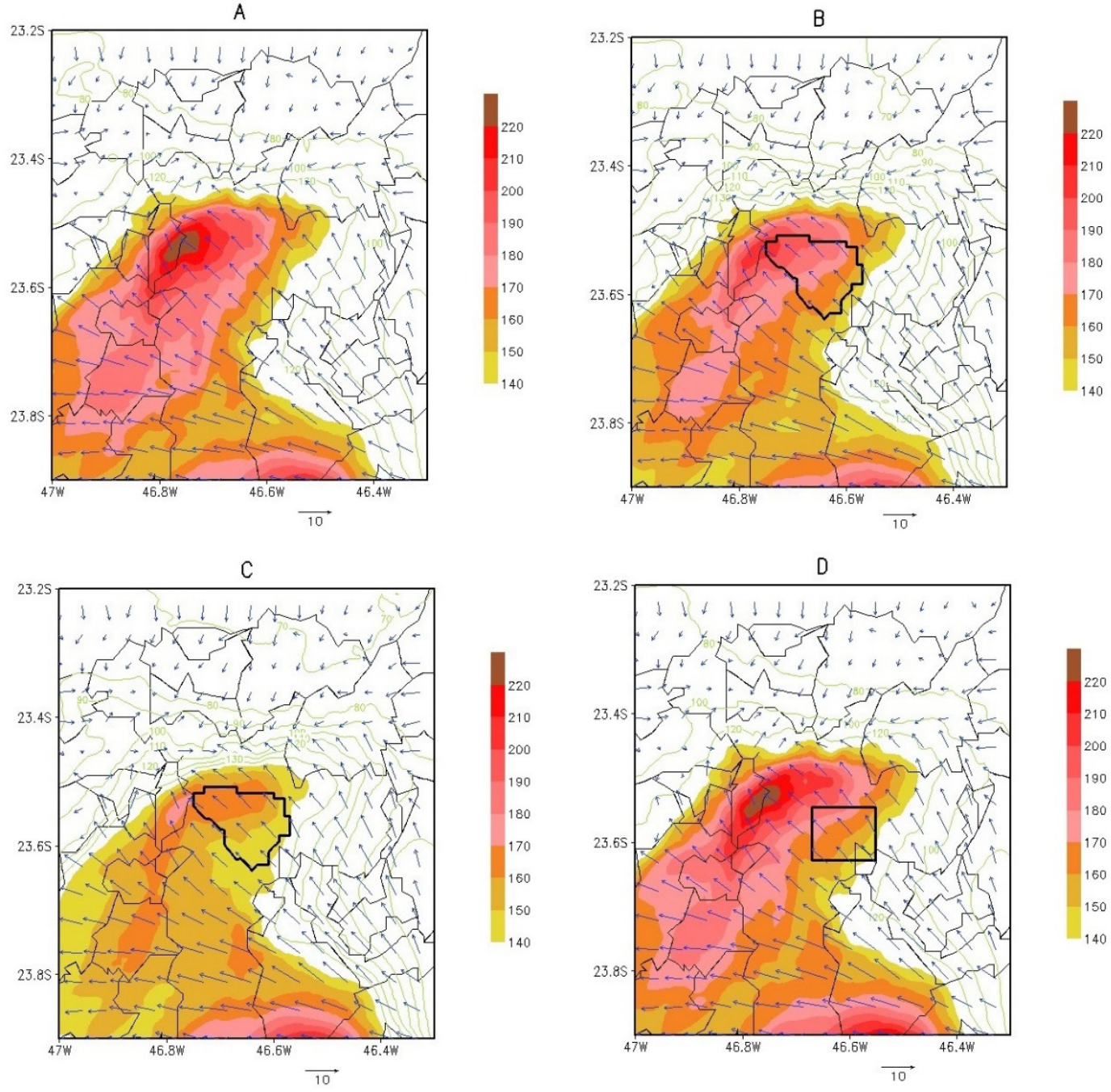

Source: prepared by the authors.

Wind direction was an important factor for determining ozone concentrations in all scenarios. The southeast winds flowing from the ocean to the continent (blue arrows in Figure 2) due to the temperature contrasts between land and ocean, form the sea breeze (CARRERA; SILVA DIAS, 1990). The high $\mathrm{O}_{3}$ concentrations in this region characterize precisely the sea breeze front - the limit of the sea breeze intrusion over the continent at this hour. The southeast winds flow over polluted regions on the coast 
and in the south and centre of São Paulo city and meet the stagnant air over the north of the expanded centre (possibly induced by urban rugosity), increasing ozone concentration in this region. We analysed wind direction data in the available stations from the CETESB during the month of January in 2014, and the sea breeze influenced the MASP on 22 days of the month, meaning that southeast winds prevailed on the majority of days during this month, particularly during the hottest days (when there is a sharp contrast between ocean and continent temperatures which exacerbate the sea breeze) (CARRERA; SILVA DIAS, 1990). Wind speed, however, is known to be overestimated by the WRF model near surface levels (MIAO et al., 2015), so pollution transport might not occur as strongly in a real-world situation. The use of coupled urban canopy models should improve these results.

Although concentrations are predominantly high and exceed the AQS in all scenarios, scenario B presents maximum concentrations near $200 \mu \mathrm{g} \cdot \mathrm{m}^{-3}$, which are $20 \mu \mathrm{g} \cdot \mathrm{m}^{-3}$ lower than the control simulation (A). It is estimated that for every $10 \mu \mathrm{g} \cdot \mathrm{m}^{-3}$ increase in ozone concentrations, the risk of respiratory and cardiovascular mortality increases in $1 \%$ (AMANN et al., 2008). So, the lower concentrations in scenario B represent an important protection for public health, particularly because acute health effects occur in higher concentration thresholds. Moreover, the area of exceedance of the attention level (8-hour average $>200 \mu \mathrm{g} \cdot \mathrm{m}^{-3}$ ) in scenario B is smaller than in the control scenario (A) (by the smaller dark red and no brown contours), which is crucial due to the high population density in the MASP, with thousands of people living in a few blocks. The decrease in total number of vehicles in the domain, from 8 to 7 million, together with the $50 \%$ decrease in emissions in the expanded centre, are likely associated to this improvement in air quality.

In Scenario C (sustainable transition), emissions were totally removed from the expanded centre and significantly decreased $(-52 \%)$ in the entire domain from 12 to 19 local time. Markedly lower concentrations were simulated compared to the control scenario $\left(170 \mu \mathrm{g} \cdot \mathrm{m}^{-3}\right.$ compared to $\left.220 \mu \mathrm{g} \cdot \mathrm{m}^{-3}\right)$. Therefore, the attention level was not exceeded, which shows the great potential of this scenario in the environmental/health protection for millions of inhabitants. There was also a small decrease in the area of AQS exceedance. The sustainable transition demonstrated the greatest efficiency in improving air quality even during a period with atmospheric conditions extremely favourable for ozone concentration.

Scenario D (Vehicle Free Zone), however, did not present any environmental/health gains. Concentrations remain in similar levels, exceeding the AQS and the attention level in a large area. Removing emissions in a smaller central area, but without other transport policies outside this area (i.e., without decreasing vehicle numbers or emissions in the rest of the MASP), did not impact ozone concentration levels as the other DRPs. As a matter of fact, the decrease of precursor emission in smaller areas, although decreasing the concentration of some pollutants, might lead to the "urban background effect" (a well-known effect of local increase in ozone in urban areas located away from emission sources, such as urban parks and residential areas). 
The next case (Figure 3), at 19 local time on 31/01/2014, presents a very different situation. The sea breeze was stronger on this day, a situation which promoted better pollutant dispersion conditions. The AQS was exceeded, but in smaller, more distant areas northwest of the MASP. Maximum concentrations reached $180 \mu \mathrm{g} \cdot \mathrm{m}^{-3}$ in the control scenario and the attention level was not reached.

Figure 3: Simulations in each scenario (A, B, C, D) at 19 LT, 31/01/2014: municipal limits (thin black contours), areas of emission change (thick black contours), wind direction and intensity (blue arrows, size ' 10 ' below each image $=10$ $\mathrm{m} . \mathrm{s}^{-1}$ ) and areas of exceedance of the AQS in the MASP (warm colour bar on the right, $\left.\mu \mathrm{g} \cdot \mathrm{m}^{-3}\right)$. Green hollow contours indicate concentrations within the AQS.
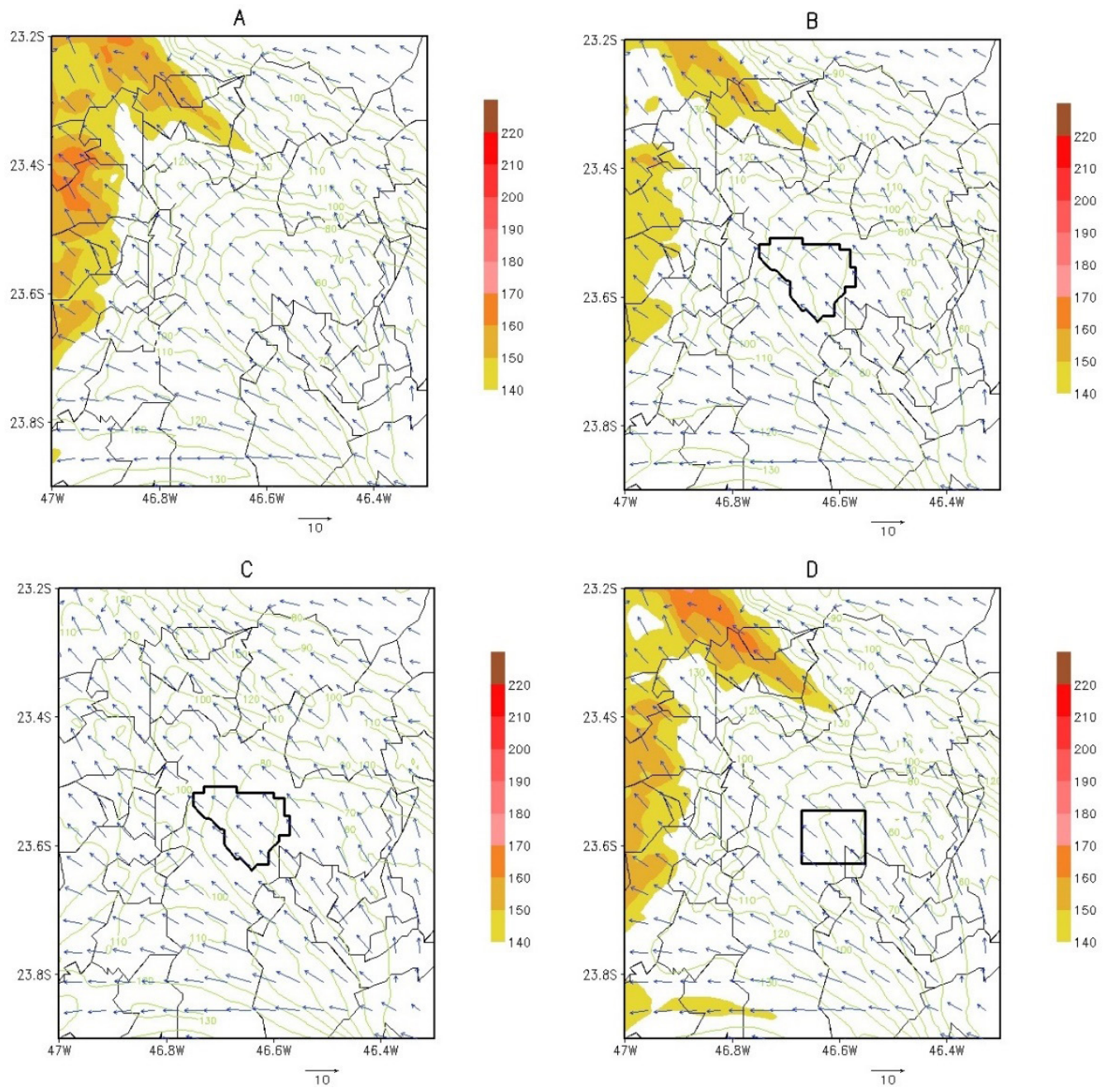

Source: prepared by the authors. 
These conditions promoted more efficient dispersion of ozone in all scenarios. In scenarios $\mathrm{A}, \mathrm{B}$ and $\mathrm{D}$, areas with $\mathrm{AQS}$ exceedance occur at the north-western boundaries of the domain, in other municipalities of the MASP (e. g. Franco da Rocha). In scenarios $A$ and $\mathrm{D}$, these pollution plumes form a large area of exceedance which extends from the northwest to the southwest of the domain boundaries. In scenario B, instead, two smaller and isolated pollution plumes occur, located to the north and to the west, separated by an area where the AQS is not exceeded. In scenario $B$, maximum simulated concentrations were $150 \mu \mathrm{g} \cdot \mathrm{m}^{-3}$, which was $10 \mu \mathrm{g} \cdot \mathrm{m}^{-3}$ lower than scenarios A and D. Once again, scenarios $\mathrm{A}$ and $\mathrm{D}$ do not present considerable differences, either spatially, either in terms of concentration levels. The most efficient decrease among the scenarios was again simulated in scenario $\mathrm{C}$, where the AQS was not exceeded in the entire domain, resulting in total protection of the population - that is, based on the current state-level air quality.

The next case chosen for analysis, at 16 local time on 01/02/2014, presents an intermediate situation between the two previously evaluated cases considering the atmospheric conditions (moderate stagnation). 
Figure 4: Simulations in each scenario (A, B, C, D) at 16 LT, 01/02/2014: municipal limits (thin black contours), areas of emission change (thick black contours), wind direction and intensity (blue arrows, size '10' below each image $=10$ $\mathrm{m} . \mathrm{s}^{-1}$ ) and areas of exceedance of the AQS in the MASP (warm colour bar on the right, $\left.\mu \mathrm{g} \cdot \mathrm{m}^{-3}\right)$. Green hollow contours indicate concentrations within the AQS.
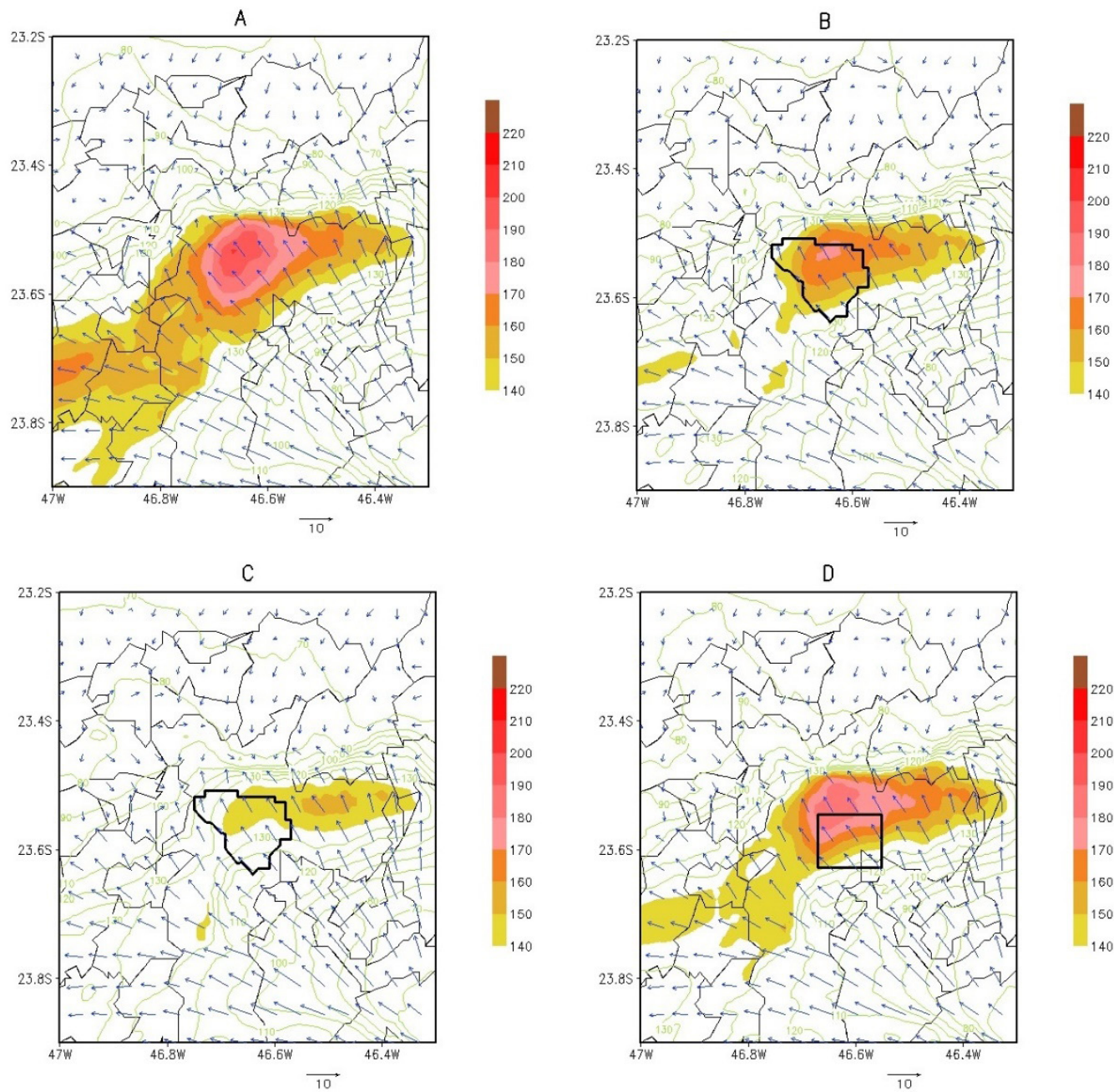

Source: prepared by the authors.

The spatial and concentration differences among the simulations are fairly evident. In the control scenario (A), the AQS is exceeded in an extensive area, ranging from the northeast to the southwest of São Paulo, also reaching other municipalities in the MASP (e.g. Cotia). Maximum concentrations $\left(180 \mu \mathrm{g} \cdot \mathrm{m}^{-3}\right)$ are located near the centre of São Paulo and the east districts, areas of high population density. In scenario B, maximum concentrations reached $170 \mu \mathrm{g} \cdot \mathrm{m}^{-3}$, which was $10 \mu \mathrm{g} \cdot \mathrm{m}^{-3}$ lower than the control scenario. 
However, the total area of exceedance is markedly reduced, avoiding AQS exceedances particularly in areas of west and southwest São Paulo, and other municipalities, and with slight decrease to the east. Scenario $\mathrm{C}$ represents even greater environmental gains, further decreasing the area of AQS exceedance, even compared to scenario $\mathrm{B}$. In addition, maximum concentrations reached $150 \mu \mathrm{g} \cdot \mathrm{m}^{-3}$, which was $30 \mu \mathrm{g} \cdot \mathrm{m}^{-3}$ lower than the control case. In Scenario D, there is a slight decrease in the area of AQS exceedance compared to the control scenario.

We present a table with the air quality impacts and the qualitatively assessed environmental justice in each scenario.

Table 1 - Number of hours in which the AQS was exceeded in each scenario for the entire simulation period, the time periods of exceedance and environmental justice promoted by each DRP.

\begin{tabular}{|c|c|c|c|c|}
\hline \multicolumn{1}{|c|}{ Day } & A (CTLR) & B (UT) & C (SUST) & D (VFZ) \\
\hline $28 / 01$ & $\begin{array}{c}6(15-20 \\
\text { hrs })\end{array}$ & $\begin{array}{c}5(15-19 \\
\text { hrs })\end{array}$ & 0 & $6(15-20 \mathrm{hrs})$ \\
\hline $29 / 01$ & $9(14-22 \mathrm{hrs})$ & $\begin{array}{c}8(15-22 \\
\text { hrs })\end{array}$ & $\begin{array}{c}4(16-19 \\
\text { hrs })\end{array}$ & $9(14-22 \mathrm{hrs})$ \\
\hline $30 / 01$ & $\begin{array}{c}8(15-22 \\
\text { hrs })\end{array}$ & $\begin{array}{c}7(15-21 \\
\text { hrs })\end{array}$ & $\begin{array}{c}3(16-18 \\
\text { hrs })\end{array}$ & $8(15-22 \mathrm{hrs})$ \\
\hline $31 / 01$ & $\begin{array}{c}7(15-21 \\
\text { hrs })\end{array}$ & $\begin{array}{c}5(16-20 \\
\text { hrs })\end{array}$ & $\begin{array}{c}3(16-18 \\
\text { hrs })\end{array}$ & $7(15-21 \mathrm{hrs})$ \\
\hline $01 / 02$ & $7(15-21$ & $\begin{array}{c}6(15-20 \\
\text { hrs })\end{array}$ & $\begin{array}{c}5(15-19 \\
\text { hrs })\end{array}$ & $8(14-21 \mathrm{hrs})$ \\
\hline $\begin{array}{c}\text { Total hours of } \\
\text { exceedance }\end{array}$ & 37 & 31 & 15 & 38 \\
\hline $\begin{array}{c}\text { Difference from } \\
\text { CTRL }\end{array}$ & N/A & -6 & -22 & +1 \\
\hline $\begin{array}{c}\text { Environmental } \\
\text { Justice }\end{array}$ & Low & High & Highest & Lowest \\
\hline
\end{tabular}

Source: prepared by the authors.

The hourly analysis of the AQS considers an average composed by the current hour plus the previous 7 hours, so for example, the average at 15 hours is composed by the hours from $8 \mathrm{AM}$ to $3 \mathrm{PM}$. This way, afternoon maxima influence both the afternoon averages (composed of morning and afternoon hours) and evening averages (composed of afternoon and evening hours). Therefore, the hourly pattern in table 1 is strongly associated to the intensity of solar radiation reaching the surface, higher in the afternoon, when there is also availability of ozone precursors (NOx and VOCs). Most exceedances of the AQS were simulated from 15 to 21 hours.

During the simulated 5-day period, there were a total of 37 hours of AQS exceed- 
ance in scenario A, conditions close to "business-as-usual", which are characterized by low environmental justice, as explained in the introduction section. In scenario B, urban toll, the AQS was exceeded in a total of 31 hours, resulting in six less hours than scenario A. This shows that this DRP presents potential to decrease the total hours of AQS exceedance, and with maximum concentrations about 10 to $20 \mu \mathrm{g} \cdot \mathrm{m}^{-3}$ lower than the control scenario, representing reasonable improvements in environmental conditions and population health protection, comparable to the results shown by Kelly et al. (2011) in the congestion charging scheme in London.

Scenario C, representing an optimized public transportation system after a future sustainable transition, is the most efficient scenario in reducing ozone concentrations, with 22 less hours of AQS exceedance compared to the control scenario (total of 15). There are less hours of exceedance at the end of the afternoon - resulting from decreased afternoon emissions. This demonstrates the efficiency of aggressive emission control policies, and in this case, directly aimed at avoiding ozone formation - focusing at the hours of the day with greater availability of both sunlight and precursor pollutants. These results show that a DRP implemented at hours with greater sunlight positively affects ozone air quality for several following hours.

Scenario D, Vehicle Free Zone, presented one additional hour of exceedance of the AQS compared to the control simulation (A), with a total of 38 hours, possibly due to intricate atmospheric chemistry mechanisms, such as a change in NOx/VOCs ratio, which could be better explored in future studies.

The analysis of the air quality simulations, combined with the urban mobility characteristics of each DRP, resulted in different environmental justice considerations for each scenario. In scenario B, because investments from the toll tax payment could be used to improve public transport conditions for the entire MASP, including access to other municipalities, there is democratization of transport and access to the urban spaces. Along with moderate improvements for air quality, this scenario resulted in higher environmental justice compared to the current situation (scenario A), and it is fairly possible to achieve if urban planning is directed towards these policies. Scenario C represents the highest environmental justice because of the intense decrease in emissions and great improvements in public transport. However, scenario $\mathrm{C}$ may not be easy to achieve if urban management does not promote massive investments in public transport and clean energy, so it is distant from current conditions. Among the analysed options, Scenario D would be the easiest and quickest achievable DRP at the moment. However, a driving restriction in the city centre without addressing transport in the rest of the MASP presents difficulties for access and would not counter the natural increase in individual vehicles. Added to the fact that the simulations did not indicate any environmental gains for ozone, scenario D presents the worse environmental justice among the evaluated possibilities. 


\section{Conclusions and Final Considerations}

In this study, we considered co-benefits resulting from strategies of urban mobility and driving restriction policies (DRP) to confront both the ozone air pollution and urban mobility problems in the Metropolitan Area of São Paulo. We used the WRF/Chem model to design four scenarios: control (A), urban toll (B), sustainable transition (C) and Vehicle Free Zone (D). We performed simulations during a period with atmospheric conditions extremely favourable for ozone concentration. The air quality standard for ozone was exceeded 37 times in the control case, which was consistent with local observations (CETESB, 2015).

Results pointed that scenario $\mathrm{C}$, a hypothetical future sustainable transition, resulted in 22 less exceedances of the air quality standard and the lowest ozone concentrations. It demonstrated that an aggressive control of vehicular pollution emission, focused on the hours of the day more favourable for ozone production (after 12 hours), is the best strategy for controlling this pollutant, even during a period with extremely favourable atmospheric conditions for ozone concentration. Combining the improvements in the access to the city with the environmental gains, it is the best environmental justice scenario. However, reaching such a state of sustainability requires long-term, heavy loads of investments and total priority for public and sustainable modals of transport, inside and outside the restriction area, so that driving restrictions result only in less automobile use and not less access to the city. The urban toll scenario (B) was a moderately effective strategy to mitigate ozone pollution, resulting in six less hours of exceedance (total of 31) and a moderate decrease in pollutant concentrations. If such a concept of urban toll is possible, it could lead to greater public transport investments, combining more just access to the city with moderate environmental gains resulted in a better environmental justice compared to current situations, although not ideal as in scenario C. Air quality simulations for scenario D (Vehicle Free Zone), on the other hand, did not present much difference compared to the control simulation. This suggests that a policy focused on solely a small area, without considering transport integration, that does not result in a decrease in the overall number of vehicles in the MASP in the long term and without considering the complex atmospheric chemistry reactions governing ozone concentrations, would result in social externalities by restricting transport to the centre and without the environmental improvements concerning ozone as the other scenarios.

The simulations strongly suggest that DRPs can affect ozone pollution not only over the restriction area, but in locations tens of $\mathrm{km}$ downwind, in other municipalities of the Metropolitan Area, due to atmospheric transport, which has implications for environmental justice at the regional level. A restriction focusing on hours of the day with higher sunlight resulted in a decrease in ozone concentrations for several following hours. Driving restriction policies offer unique opportunities to confront both air pollution and urban mobility problems. But decision makers must consider that the current state of public transport in São Paulo is not adequate for 
implementing an urban toll or vehicle free zone, due to the inefficient quality of public transport. Before implementing any DRP, public transport must be expanded and improved in this area, both in local and intercity level, particularly those with low or zero emissions, such as the underground metro and electric buses. This is the most promising path towards a sustainable transport transition in the future, so that an overall improvement of quality of life in the urban environment is attained, promoting a fairer environmental justice, healthier conditions and a more democratic access to the urban spaces by shifting the focus towards public and non-motorized modes of transport - which are optimized in terms of energy consumption, emission abatements and use of the urban spaces.

\section{Acknowledgements}

We thank Fundação de Amparo à Pesquisa do Estado de São Paulo (FAPESP -Research Support Foundation of the São Paulo State) for funding this research under grant number 2012/12216-5.

\section{References}

ALVIM D.S.; GATTI L.V.; CORREAA S.M.; CHIQUETTO J.B.; DE SOUZA ROSSATTI C.; PRETTO A.; DOS SANTOS M.H.; YAMAZAKI A.; ORLANDO J.P.; SANTOS G.M. Main ozone-forming VOCs in the city of Sao Paulo: observations, modelling and impacts. Air Quality, Atmosphere \& Health. New York, v. 10, n.4, p. 421-435, 2017.

AMANN M.; DERWENT, D.; FORSBERG, B.; HÄNNINEN, O.; HURLEY, F.; KRZYZANOWSKI, M.; DE LEEUW, F.; LIU, S. J.; MANDIN, C.; SCHNEIDER, J.; SCHWARZE, P.; SIMP$\mathrm{SON}, \mathrm{D}$. Health risks of ozone from long-range transboundary air pollution. Copenhagen: World Health Organization Regional Office for Europe, 2008.

ANDRADE M.D.; YNOUE R.Y.; FREITAS E.D.; TODESCO E.; VARA VELA A.; IBARRA S.; MARTINS L.D.; MARTINS J.A.; CARVALHO V.S. Air quality forecasting system for Southeastern Brazil. Frontiers in Environmental Science. Lausanne, v. 3, p.1-14, Feb. 2015.

BRASSEUR G., et al. Atmospheric chemistry and global change. Oxford: Oxford University Press, 1999.

CARRERA, C. V. M.; SILVA DIAS, P. L. Estudo da entrada da brisa marítima no estado de São Paulo. In: VI CONGRESSO BRASILEIRO DE METEREOLOGIA: ANAIS..., Salvador. 1990, p. 315-319.

CARVALHO A.M.; KRECL P.; TARGINO A.C. Variations in individuals' exposure to black carbon particles during their daily activities: a screening study in Brazil. Environmental Science and Pollution Research. New York, n. 25, v.19, p. 18412-18423, 2018. 
CETESB - Companhia Ambiental do Estado de São Paulo, Relatório Anual da Qualidade do Ar do Estado de São Paulo, 2009. São Paulo: Divisão de Análise de dados, 2010.

CETESB - Companhia Ambiental do Estado de São Paulo, Relatório Anual da Qualidade do Ar do Estado de São Paulo, 2014. São Paulo: Divisão de Análise de dados, 2015.

CETESB - Companhia Ambiental do Estado de São Paulo, Relatório Anual da Qualidade do Ar do Estado de São Paulo, 2017. São Paulo: Divisão de Análise de dados, 2018.

COOKSON G.; PISHUE B. Inrix global traffic scorecard. Kirkland: INRIX Research, 2017.

CHIQUETTO J.B.; RIBEIRO F.N.; ALVIM D.S.; YNOUE R.Y.; DA SILVA J.; SILVA M.E. Transport of Pollutants by the Sea Breeze in São Paulo under the South Atlantic High. Revista do Departamento de Geografia, São Paulo, v. p 148-161, Set. 2018. Special Issue.

DAVIS, L.W. Saturday driving restrictions fail to improve air quality in Mexico City. Scientific Reports (Nature) 7, p. 41652, 2017. Available at < https://www.nature.com/articles/srep41652> Access on: 17 August 2018.

GRELL, G.A.; PECKHAM, S.E.; SCHMITZ, R.; MCKEENM S.A.; FROST, G.; SKAMAROCK, W.C.; EDER, B. Fully coupled "online" chemistry within the WRF mode. Atmospheric Environment. Amsterdam, v 39, n 37, p 6957-6975, December 2005.

Health Effects Institute. State of Global Air 2018. Boston, 2018. Available at: < https://www. stateofglobalair.org/sites/default/files/soga-2018-report.pdf> Access on: 15 May 2020.

HOLMAN C.; HARRISON R.; QUEROL X. Review of the efficacy of low emission zones to improve urban air quality in European cities. Atmospheric Environment. Amsterdam, v. 111, p. 161-169, Jun 2015.

KELLY F; ANDERSON H.R.; ARMSTRONG B.; ATKINSON R.; BARRATT B.; BEEVERS S.; DERWENT D.; GREEN D.; MUDWAY I.; WILKINSON P. The impact of the congestion charging scheme on air quality in London. Part 1. Emissions modeling and analysis of air pollution measurements. Health Effects Institute. Boston, Apr 2011.

KRAAS F; MERTINS G. Megacities and global change. In KRAAS, F.; AGGARWAL, S.; COY, M.; MERTINGS, G. Megacities: Our Global Urban Future. Dordrecht: Springer, 2014, p 1-6.

LACERDA, S.M. Precificação de congestionamento e transporte coletivo urbano. BNDS setorial, Rio de Janeiro, n. 23, p. 85-99, mar 2006. Available at < https://web.bndes.gov.br/bib/jspui/ handle/1408/2439> Access on: 10 Jan 2019.

LUCAS, K. Transport and social exclusion: Where are we now? Transport Policy, Amsterdam, v. 20, p. 105-113, Mar 2012.

MARTÍNEZ, C.F.; HODGSON, F; MULLEN, C.; TIMMS, P. Creating inequality in accessibility: The relationships between public transport and social housing policy in deprived areas of Santiago de Chile. Journal of Transport Geography, Amsterdam, v. 67, p 102-109, Feb 2018. 
MIAO Y.; LIU S.; ZHENG Y.; WANG S.; CHEN B. Numerical study of the effects of topography and urbanization on the local atmospheric circulations over the Beijing-Tianjin-Hebei, China. Advances in Meteorology, London, p 1-16, Mar 2015. Special Issue.

ROBERTS J.T.; PELLOW D.; MOHAI P. Environmental justice. In: BOMSTRÖM, M.; DAVIDSON, D. Environment and Society, London: Palgrave Macmillan, Cham, 2018, p. 233-255.

SALVO, A.; GEIGER, F.M. Reduction in local ozone levels in urban São Paulo due to a shift from ethanol to gasoline use. Nature Geoscience, London, v. 7, p 450-458, Jun 2014.

SLOVIC, A.D.; TOMASIELLO, D.B.; GIANNOTTI, M.; ANDRADE, M. F. T.; NARDOCCI, A.C. The long road to achieving equity: Job accessibility restrictions and overlapping inequalities in the city of São Paulo. Journal of Transport Geography, Amsterdam, v. 78, p. 181-193, Jun 2019.

VENTER, C.; JENNINGS, G.; HIDALGO, D.; VALDERRAMA PINEDA, A.F. The equity impacts of bus rapid transit: A review of the evidence and implications for sustainable transport. International Journal of Sustainable Transportation, Abingdon-on-Thames, v. 12, n. 2, p. 140-152, 2018.

WANG Y.; HAO J.; MCELROY M.B.; MUNGER J.W.; MA H.; CHEN D.; NIELSEN C.P. Ozone air quality during the 2008 Beijing Olympics: effectiveness of emission restrictions. Atmospheric Chemistry and Physics, Göttingen, v. 9, n. 14, p. 5237-5251, 2009.

WHO - World Health Organization. Global health risks: mortality and burden of disease attributable to selected major risks. Geneva: World Health Organization, 2009.

WHO - World Health Organization. Evolution of WHO air quality guidelines: past, present and future. Copenhagen: WHO Regional Office for Europe, 2017. Available at:

< http://www.euro.who.int/_data/assets/pdf_file/0019/331660/Evolution-air-quality.pdf> Accessed on: 12 May 2020.

YAMAWAKI, Y.; SALVI, L. T., Introdução à gestão do meio urbano. Curitiba: InterSaberes, 2013. 


\section{Júlio Barboza Chiquetto}

$\square$ juliobchiquetto@gmail.com

ORCiD: https://orcid.org/0000-0002-4013-7947
Submitted on: 19/02/2019

Accepted on: 03/07/2020

2020;23:e00082

\section{Rita Yuri Ynoue}

$\square$ ritaynoue@iag.usp.br

ORCiD: http://orcid.org/0000-0001-5810-2913

\section{Sergio Alejandro Ibarra-Espinosa}

曰sergio.ibarra@usp.br

ORCiD: https://orcid.org/0000-0002-3162-1905

\section{Flávia Noronha Dutra Ribeiro}

$\square$ flaviaribeiro@usp.br

ORCiD: http://orcid.org/0000-0001-9589-7911

\section{William Cabral-Miranda}

$\square$ williamcabral@usp.br

ORCiD: http://orcid.org/0000-0002-8391-3109

\section{Maria Elisa Siqueira Silva}

$\square$ elisasiq@usp.br

ORCiD: Não possui

http://lattes.cnpq.br/9102458241218645

How to cite: CHIQUETTO et al. Ozone Pollution and Urban Mobility Scenarios in the São Paulo Megacity. Ambiente \& Sociedade. São Paulo, v. 23, p. 1-21, 2020. 


\title{
Poluição por Ozônio e Cenários de Mobilidade Urbana na Megacidade de São Paulo
}

\author{
Júlio Barboza Chiquetto \\ Rita Yuri Ynoue \\ Sergio Alejandro Ibarra-Espinosa \\ Flávia Noronha Dutra Ribeiro \\ William Cabral-Miranda
}

São Paulo. Vol. 23, 2020

Artigo Original
Resumo: A poluição atmosférica pode ser agravada devido à precárias condições de mobilidade urbana, como ocorre em São Paulo. Visando avaliar os impactos na poluição por ozônio e as consequências para a justiça ambiental, 3 cenários de políticas de restrição veicular foram simulados com o modelo WRF/Chem: pedágio urbano, transição sustentável e centro sem veículos. Os resultados indicaram que o pedágio urbano levou a uma redução de $20 \mu \mathrm{g}$.m-3 nas médias das máximas de 8 horas, e evitou seis ultrapassagens do padrão de qualidade do ar. A transição sustentável teve máximas até $50 \mu \mathrm{g}$.m-3 mais baixas e evitou 22 ultrapassagens. $\mathrm{O}$ centro sem veículos não demonstrou vantagens. Para a implementação de um sistema de transporte público adequado, são necessários expressivos investimentos para se atingir melhorias na qualidade do ar com a maior justiça ambiental possível, buscando a proteção da saúde da população juntamente à democratização do acesso aos espaços urbanos.

Palavras-chave: Poluição do ar; gestão ambiental; mobilidade urbana; São Paulo; modelagem de qualidade do ar.

Como citar: CHIQUETTO et al. Poluição por Ozônio e Cenários de Mobilidade Urbana na Megacidade de São Paulo. Ambiente \& Sociedade. São Paulo, v. 23, p. 1-21, 2020.

DOI: http://dx.doi.org/10.1590/1809-4422asoc20190008r2vu2020L6AO 


\title{
Contaminación por Ozono y escenarios de movilidad urbana en la megaciudad de São Paulo
}

\author{
Júlio Barboza Chiquetto \\ Rita Yuri Ynoue \\ Sergio Alejandro Ibarra-Espinosa \\ Flávia Noronha Dutra Ribeiro \\ William Cabral-Miranda \\ Maria Elisa Siqueira Silva
}

São Paulo. Vol. 23, 2020

Artículo original
Resumen: La contaminación atmosférica puede agravarse debido à la movilidad urbana ineficiente, como en São Paulo. Visando avaliar los impactos em la contaminación por ozono y las consecuencias para la justicia ambiental, se simularan 3 escenarios de restricción vehicular con en el modelo WRF/Chem: peaje urbano, transición sustentable y centro sin vehículos. Los resultados indicaron que el peaje urbano condujo a una reducción de $20 \mu \mathrm{g} . \mathrm{m}-3$ en las concentraciones medias máximas de 8 horas, y evito 6 excedencias de las normas de calidad del aire. La transición sustentable tuvo un máximo de hasta $50 \mu \mathrm{g} \cdot \mathrm{m}-3$ más bajo e 22 excedencias evitadas. El centro sin vehículos no presento ventajas. Para la implementación de un transporte público adecuado, se necesitan inversiones significativas para lograr mejoras en la calidad del aire con la mayor justicia ambiental posible, buscando proteger la salud de la población junto con la democratización del acceso a los espacios urbanos.

Palabras-clave: Contaminación atmosférica, gestión ambiental, movilidad urbana, São Paulo, modelo de calidad del aire.

Como citar: CHIQUETTO et al. Contaminación por Ozono y Escenarios de Movilidad Urbana en la Megaciudad de São Paulo. Ambiente \& Sociedade. São Paulo, v. 23, p. 1-21, 2020.

DOI: http://dx.doi.org/10.1590/1809-4422asoc20190008r2vu2020L6AO 